Agnieszka Szplit

Uniwersytet Jana Kochanowskiego, Kielce

E-MAIL: agnieszka.szplit@gmail.com

\title{
O nauczycielskiej „jakości z wnętrza” - rozważania nad „modelem cebuli” Freda Korthagena
}

\section{STRESZCZENIE}

Zaprezentowany tekst przybliża ważną współczesną koncepcję - „model cebuli” Freda Korthagena. Wskazuje jej ugruntowanie w opracowaniach naukowych oraz adekwatność do dyskusji nad zmianami edukacyjnymi i rozważaniami dotyczącymi profesjonalizmu nauczycieli. Autorka wykorzystuje model również do opisu profilu nauczycieli akademickich, wśród których prowadziła wywiady. W efekcie tych zabiegów ukazuje harmonię pomiędzy warstwami tytułowej „cebuli” i drogę „przepływu” nauczycielskiej „jakości z wnętrza” oraz podkreśla rolę wielopoziomowego kształcenia nauczycieli.

SŁOWA KLUCzOWE: nauczyciel, „model cebuli”, jakość nauczania, kompetencje

\section{Wprowadzenie}

Współczesna dyskusja nad jakością kształcenia i profesjonalizmem nauczycieli często zmierza do stworzenia określonego modelu dobrego nauczyciela. Pojawiają się liczne skale, ramy kwalifikacji i wskazania, w jakim kierunku należy kształcić nauczycieli lub jak kierować ich rozwojem. To wszystko jednak nie daje pełnego obrazu nauczyciela, nie ukazuje tego, co najważniejsze w tej pracy - talentu, duszy, wnętrza. Propozycją wskazującą na konieczność wielotorowego myślenia o nauczycielu i ukazującą mnogość czynników, które w ostatecznym rozrachunku stanowią o jakości jego pracy jest „model cebuli” Freda Korthagena. Model ten pozwala na poszukiwanie i opisanie „prawdziwej jakości” w pracy nauczyciela, nie zaś postrzeganej przez pryzmat efektów w programie nauczania czy zapisy w teczkach awansowych.

Celem poniższego tekstu jest ukazanie źródeł potencjalnego sukcesu pedagogicznego w odniesieniu do modelu Freda Korthagena. Tekst jest głosem w dyskusji poświęconej edukacji nauczycieli i jednoznacznie krytykuje ich kształcenie „rzemieślnicze”, czysto kompetencyjne. Rozważania zawarte w nim podkreślają rolę harmonii pomiędzy poszczególnymi elementami stanowiącymi o jakości nauczania i konieczność wielotorowego i wielopoziomowego kształcenia nauczycieli. 


\section{„Model cebuli” $\mathrm{i}$ jego ugruntowanie w literaturze pedagogicznej}

Zdaniem Freda Korthagena nie jest możliwe stworzenie określonego, zamkniętego opisu „dobrego nauczyciela”. Jego propozycja zawiera jednak opis elementów, które stanowią „esencję dobrego nauczyciela” (Korthagen, 2004). Autor charakteryzuje nauczyciela, ujmując różne poziomy „bycia dobrym nauczycielem”, i tworzy model nazwany „modelem cebuli” (Korthagen, 2004; Korthagen i Vasalos, 2008), ze względu na umieszczenie w nim wielu „warstw”, z których tylko najbardziej zewnętrzne mogą być zauważone przez obserwujących. Korthagen (2004) opisuje sześć warstw tytułowej „cebuli” jako konstytutywne składniki dobrego nauczyciela. Są to, wymieniając od najbardziej centralnej warstwy - misja, tożsamość, przekonania, kompetencje, zachowanie oraz środowisko.

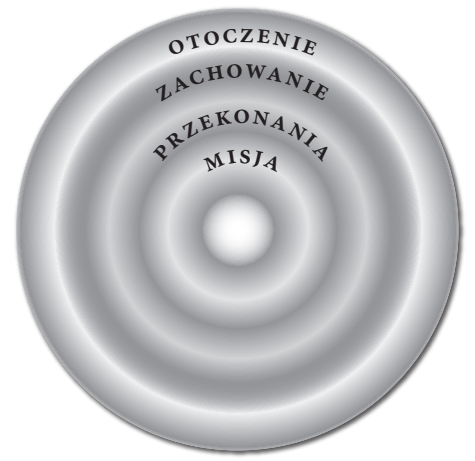

Źródło: na podstawie: Korthagen i Vasalos (2008, s. 3), tłum. A. Szplit

Najbardziej zewnętrzną warstwą jest środowisko, które stanowi klasa szkolna, uczniowie i sama szkoła. Refleksyjny nauczyciel, dokonując analizy swojej pracy, stawia sobie pytanie: Co napotykam w swojej pracy?/Z czym się mierzę? Rozważania i badania naukowe dotyczące środowiska pracy nauczyciela często oscylują wokół pojęcia „kultura szkoły” (Nowosad, 2019), które jest definiowane jako zbiór przekonań, poglądów i relacji oraz zasad obowiązujących w instytucji (Ward i Burke, 2004, s. 1), kształtowanych i podtrzymywanych przez nauczycieli, uczniów, pracowników szkoły i rodziców uczniów (Czerepaniak-Walczak, 2015, s. 80). Z perspektywy nauczyciela mówi się o kulturze „pokoju nauczycielskiego” (Czerepaniak-Walczak, 2015, s. 80), nieformalnej kulturze nauczycielskiej, czy nawet o nauczycielskiej kulturze ulicznej dostrzeganej w klasie i kulturze oporu nauczycielskiego (Babicka-Wirkus, 2019, s. 189-19o). Opisanie środowiska nauczyciela to także ogląd systemu kształcenia czy nadzoru pedagogicznego (Mazurkiewicz, 2011). 
Kolejną warstwą opisaną przez Korthagena jest zachowanie nauczycieli. Zdaniem autora jest ono tym aspektem, na którym największą uwagę skupiają początkujący nauczyciele, uznając swoje zachowanie za czynnik bezpośrednio wpływający na zachowanie uczniów (pytanie: Co robię?) i poszukując sposobów na poradzenie sobie z problemami w klasie poprzez modyfikowanie swoich zachowań. Analiza zachowań nauczyciela stanowi znaczną część opracowań metodycznych i prac naukowych. Wymienić można chociażby słynną publikację Johna Hattie opartą na 15-letnich badaniach i jego imponujących metaanalizach (Hattie, 2009), które wskazują na rozmaite zachowania nauczycieli, uznane za efektywne w procesie dydaktycznym, i kształtują obraz „dobrego” nauczyciela.

Nieco bardziej wewnętrzną warstwą „cebuli”, którą wskazuje Korthagen, są kompetencje, traktowane jako połączenie wiedzy, umiejętności i postaw. Taki sposób ujęcia kompetencji jest obecny w wielu współczesnych opracowaniach standardów kompetencji, np. w Skali Opisu Kompetencji Nauczycieli Języków Obcych EAQUALS (Szplit, 2019, 78-83). Tak rozumiane kompetencje odnoszą się do pytania: $W$ czym jestem dobry? i nie oznaczają tego samego, co zachowanie. To bowiem, czy określone kompetencje przyczynią się do powstania danych zachowań, zależy również od okoliczności, w których kompetencje się przejawiają (Caprara i Cervone, 2003).

Kolejnymi warstwami „cebuli” są przekonania (W co wierzę?) i tożsamość (Kim jestem?). Pierwszą z wymienionych warstw stanowią przekonania dotyczące procesu dydaktycznego, modele mentalne, osobiste zrozumienie takich pojęć, jak wiedza, uczenie się czy nauczanie. Korthagen podkreśla istotną rolę przekonań w kształtowaniu praktyki dydaktycznej nauczyciela. Założenia te potwierdza wiele współczesnych badań i rozważań poświęconych „praktycznym teoriom nauczycieli” (Mizerek, 1999, s. 129), „osobistym teoriom edukacyjnym” (Gołębniak, 200o, s. 238) czy „pedagogicznym” (Klus-Stańska, 2010, s. 63). Tożsamość jest natomiast rozumiana przez Korthagena jako opinia, którą człowiek ma o samym sobie i swojej roli zawodowej. W związku z tym, że jest ona dość stała, nie jest możliwe celowe wpływanie na jej zmianę. Autor odnajduje jednak w literaturze opisy takich działań, które oddziałują na budowanie tożsamości. Można bowiem ukierunkowywać budowanie tożsamości człowieka poprzez dostarczanie mu sytuacji przyjaznych, które same w sobie wywołują określony kierunek zmian.

Najgłębsza warstwa „cebuli” to misja, którą Korthagen rozumie jako „nadawanie znaczenia własnej egzystencji” (2004, s. 85), świadomość pochodzenia własnej inspiracji oraz wartości i ideały, które jednostka uznaje za zasadnicze dla własnego życia czy pracy. Poziom misji ma, zdaniem autora, zasadnicze 
znaczenie w pracy nauczyciela, a łączy ją on z duchowością i cechami osobistymi człowieka, np. kreatywnością, odwagą, wrażliwością, decyzyjnością, spontanicznością czy też zaangażowaniem i umiejętnością dostosowania się do sytuacji.

Zaprezentowany model teoretyczny znajduje szerokie zastosowanie w badaniach i rozważaniach pedagogicznych w świecie (np. Sööt, 2015; Ekizer i Cephe, 2017; Körkkö, 2019), a wskazywane przez Korthagena warstwy są również osobno analizowane w rozprawach naukowych. Istotną wartością „modelu cebuli” jest jednak zwrócenie uwagi na relacje pomiędzy określonymi „warstwami” oraz wzajemne zależności między nimi.

\section{Wzajemne wpływy warstw „cebuli”}

Dla rozważań pedagogicznych poświęconych profesjonalizmowi nauczycieli oraz dyskusji, skąd pochodzi „jakość” w pracy nauczyciela, istotne są relacje pomiędzy opisanymi warstwami „cebuli”. Bardziej zewnętrzne warstwy wpływają bowiem na wewnętrzne. Środowisko zmienia zachowanie nauczyciela - inaczej pracuje on bowiem w szkole stwarzającej mu warunki do rozwoju i innowacji, a odmiennie w szkole pełnej wrogości i negatywnych nacisków. Dodatkowo, regularne powtarzanie określonych zachowań wpływa zaś na kształtowanie się specyficznych kompetencji.

Zauważyć jednak można i wpływy zmierzające w odwrotnym kierunku: $z$ wnętrza do warstw zewnętrznych. Kompetencje nauczyciela determinują jego zachowania, które z kolei wywierają wpływ na zachowanie uczniów, czyli modyfikują środowisko. Analiza tego kierunku stała się podstawą teorii Freda Korthagena i Angelo Vasalosa (2008), określającej rozwój nauczyciela jako wzbogacenie ,jakości z wnętrza”. Przyjmując założenie o wpływie wewnętrznych warstw na zewnętrzne, Korthagen (2004) stwierdza, że kompetencje nauczyciela są zdeterminowane przez jego przekonania, stworzone w oparciu o wcześniejsze doświadczenia, poznane modele zachowań, potrzeby, wartości lub uczucia, które wywołane były konkretnymi sytuacjami zawodowymi. Określenie roli uprzednich doświadczeń i przekonań nauczyciela w kształtowaniu jego profesjonalizmu jest od lat bardzo popularnym kierunkiem badawczym (np. Kolb 1984; Illeris, 2006; Szplit 2019).

Oparcie koncepcji na idei warstw ułożonych jedna na drugiej pozwala na zrozumienie mechanizmu uzyskiwania wysokiej jakości w pracy nauczyciela. Uznanie istnienia warstw wewnętrznych, głębokich, ma konsekwencje w określeniu, na czym polega rozwój zawodowy nauczyciela oraz jakie są realia wdrażania zmian edukacyjnych. Sam Korthagen podkreśla w swojej koncepcji „realistycznej” edukacji nauczycielskiej (Korthagen i in., 2001), 
że podstawę dla rozwoju zawodowego nauczyciela stanowią jego rzeczywiste doświadczenia i obawy. Autor obawia się nawet, że rzeczywisty rozwój kompetencji nauczycieli nie jest częsty. Przytacza on badania Holmesa z 1998 roku, które wykazały istnienie niewielkich zmian w edukacji mimo wprowadzania kolejnych innowacji i pobudzania rozwoju zawodowego nauczycieli. Korthagen tłumaczy tę sytuację naturą człowieka. Po pierwsze, nie jest możliwe zarządzanie zmianą edukacyjną; po drugie, w naturze człowieka istnieje silny opór przed naciskiem, który pojawia się wraz z wprowadzanymi reformami. Reakcją naturalną nauczyciela pod presją jest bowiem przede wszystkim walka i opór (por. Babicka-Wirkus, 2019) lub stagnacja (Korthagen, 2001, s. 3). Reforma jest zmianą narzuconą z góry, która przeraża nauczycieli i jest odbierana przez nich jako zagrożenie dla ich profesjonalizmu.

Podobna reakcja pojawiać się może również podczas wprowadzania nowych standardów kompetencji czy zasad awansu zawodowego, które narzucają nauczycielowi kierunek rozwoju lub przymuszają go do niego. Jednak za przyczynę buntu przeciw takim zmianom Korthagen uznaje odczuwane przez nauczycieli nastawienie na odnajdywanie ich złych stron i słabości. Tworzenie i wdrażanie nowych ram kwalifikacji czy standardów nie jest bowiem efektem poszukiwania tego, co dobre i wartościowe w pracy nauczyciela, lecz skupiania uwagi na negatywnych zjawiskach występujących w pracy nauczyciela, takich jak stres czy wypalenie zawodowe.

Prawdziwa jakość w pracy nauczyciela wynika $\mathrm{z}$ istnienia tzw. cech fundamentalnych (core qualities), które Korthagen i Vasalos opisują, wykorzystując termin stworzony przez Ofmana (2000), i odróżniają od kompetencji. Są to cechy bezpośrednio związane z podstawami charakteru człowieka, które pochodzą „z jego środka”. Kompetencje (przykładowo umiejętność odniesienia się w pracy do różnych stylów uczenia się lub umiejętność podejmowania refleksji pedagogicznej) zaś nabywane są „z zewnątrz”. Dokładniejsze ich rozróżnienie obrazuje poniższa tabela.

\begin{tabular}{|l|l|}
\hline \multicolumn{1}{|c|}{ Kompetencje } & \multicolumn{1}{c|}{ Cechy fundamentalne } \\
\hline związane z działaniami & determinują, kim jest człowiek \\
\hline $\begin{array}{l}\text { związane z umiejętnościami nauczyciela do } \\
\text { „zachowania dyscypliny” lub „wyjaśniania” }\end{array}$ & ściśle związane z zaletami człowieka \\
\hline rozwijane w procesie uczenia się & wrodzone \\
\hline $\begin{array}{l}\text { można je opisać, wyróżniając poszczególne } \\
\text { elementy i komponenty }\end{array}$ & $\begin{array}{l}\text { stanowią niepodzielną całość, nie można ich } \\
\text { rozdzielać na mniejsze składowe cechy }\end{array}$ \\
\hline $\begin{array}{l}\text { związane z określoną sferą działania czło- } \\
\text { wieka }\end{array}$ & $\begin{array}{l}\text { ujawniają się niemal we wszystkich dziedzi- } \\
\text { nach życia }\end{array}$ \\
\hline
\end{tabular}

Źródło: opracowanie własne na podstawie: Korthagen i Vasalos (2008, s. 5) 
Wnioskiem z tych analiz jest stwierdzenie, że niezależnie od tego, jak bardzo nauczyciel pracuje nad rozwojem swoich kompetencji, to i tak cechy charakteru kształtują jego sposoby zachowania w pracy. Autorzy przytaczają stwierdzenie Hamacheka (1999, s. 209), że nauczyciel uczy tego, co wie w sposób świadomy, nieświadomie zaś przekazuje to kim jest. Fundamentem jakości pracy nauczycieli są zatem ich cechy osobiste i dążenia stanowiące najbardziej centralną część tytułowej „cebuli”. Są otulane, obudowywane, jak środek cebuli, kolejnymi warstwami. McInyre i Hagger (1992) zwracają jednak szczególną uwagę na fakt, że to obudowywanie, czyli pojawianie się nowych cech, jest zawsze bezpośrednio związane z cechami już istniejącymi. Nowe cechy nie pojawiają się bowiem z niczego.

Rozwój nauczyciela polega zatem na harmonizowaniu wewnętrznych i zewnętrznych warstw tytułowej „cebuli”. Jedyną metodą dokonania tego jest wykorzystanie refleksji dotyczącej relacji pomiędzy określonymi warstwami. Jeśli refleksja dotyczy najgłębszych, najbardziej centralnych warstw, nazywana jest refleksją fundamentalną. Podstawą tej refleksji są ideały, cechy fundamentalne i potencjał własny, a sama refleksja ma na celu (Korthagen, 2014):

1. Wzmacnianie świadomości istnienia własnych ideałów i cech fundamentalnych odnoszących się do określonej sytuacji, w której następuje refleksja służąca wzmacnianiu tożsamości i własnej misji,

2. zidentyfikowanie barier wewnętrznych zaburzających wykorzystanie własnych ideałów i cech fundamentalnych,

3. wzmacnianie świadomości istnienia poznawczych, emocjonalnych i motywacyjnych aspektów stanowiących ideały i osobiste cechy fundamentalne,

4. wzmacnianie świadomości (poznawczej i emocjonalnej) istnienia „tarcia" pomiędzy celami opisanymi w punkcie 1 . i 2. oraz stwarzanymi przez samego siebie barierami wewnętrznymi,

5. rozwijanie zaufania do procesów zachodzących w samym człowieku,

6. wzmacnianie wewnętrznego potencjału w odniesieniu do pojawiającej się sytuacji,

7. rozwijanie autonomii w wykorzystaniu refleksji fundamentalnej.

Rozwój zawodowy wymaga współdziałania wszystkich warstw i doświadczenia tzw. „przepływu” pomiędzy nimi. „Przepływ” i uzyskanie harmonii pomiędzy pokładami wewnętrznymi i warstwami zewnętrznymi mogą być jednak ograniczone swoistymi blokadami mentalnymi lub zachowaniami innych osób. Blokady te powstają niekiedy na bazie barier zewnętrznych 
(np. decyzje dyrektora, zasady funkcjonowania systemu oświatowego, niska motywacja uczniów), które kreują i bariery wewnętrzne. Jeśli warstwy wewnętrzne i zewnętrzne nie osiągają harmonii, efektem tego jest stres, czy nawet wypalenie zawodowe.

Zgodnie z teorią Korthagena i jego współpracowników wszelkie zmiany wychodzą z „wnętrza” człowieka. Wspomniany „przepływ” może mieć miejsce, gdy zmiana jest pożądana przez jednostkę, która czuje się w danej sytuacji komfortowo, odnajduje się w niej oraz uczy się w sposób szybki i naturalny. Rozwój rozpoczyna się z „wnętrza”, od poczucia własnej misji i tożsamości zawodowej, i przenika przez kolejne warstwy, które współgrają. To powoduje zaspokojenie trzech istotnych potrzeb: autonomii, posiadania kompetencji i potrzeby nawiązywania relacji. Tak więc niezbędnymi warunkami rozwoju kompetencji jest poczucie autonomii (której źródłem są najgłębsze warstwy „cebuli”), możliwość wykorzystania własnych zdolności i uzyskanie poczucia skuteczności własnych działań oraz pozytywne relacje z innymi. Jeśli nauczyciel rozwinie swoje własne, wewnętrzne mocne strony oraz połączy je z zaletami innych nauczycieli i uczniów, stworzy swoje własne, osobiste i skuteczne, podejście do procesu nauczania. Takie „sięgnięcie” do własnych pokładów wewnętrznych zabezpiecza nawet przed wypaleniem zawodowym (Fisher, 2011).

Jak podkreśla Korthagen, świadomość istnienia owego „wnętrza”, a zatem głębszych „warstw”, z których płynie jakość, jest znacząca również w kontekście reformowania edukacji i wdrażania innowacji. Sytuacja, w której projektujący reformę eksperci lub liderzy (jako twórcy środowiska) uważają, że sam transfer wiedzy wystarczy, by poprawić jakość edukacji, skutkuje jednotorowymi zmianami lub nawet ich brakiem.

Opisane sięganie do własnej głębi i analizowanie warstw „cebuli” jest procesem samorefleksyjnym i pozwala na zrozumienie samego siebie i własnej pracy zawodowej. Takiej refleksji poszukiwałam, analizując wywiady z nauczycielami akademickimi.

\section{Wykorzystanie „modelu cebuli” do analizy wywiadów}

Rosanne C. Zwart, Fred A.J. Korthagen i Saskia Attema-Noordewier (2014) wskazują na możliwości prowadzenia analizy przypadków $\mathrm{w}$ oparciu o „model cebuli”. Sugerując się przypadkiem opisanym przez autorów, dokonałam analizy pięciu wypowiedzi nauczycieli akademickich specjalizujących się w nauczaniu metodyki na studiach nauczycielskich. Przedstawione fragmenty stanowią część szerszych badań prowadzonych w roku 2018 wśród 14 osób, dobranych metodą kuli śnieżnej. Materiał badawczy został zebrany 
w trakcie wywiadów niestandaryzowanych i poddany analizie jakościowej w różnorodnej formie ${ }^{1}$. Podane imiona zostały zmienione ze względu na możliwość zidentyfikowania rozmówców. Przedstawione profile mają na celu zilustrowanie relacji pomiędzy wskazanymi przez Korthagena „warstwami” w oparciu o relacje samych nauczycieli.

\section{Beata}

Beata jest nauczycielem akademickim prowadzącym zajęcia z metodyki nauczania języka angielskiego na filologii, na studiach licencjackich i magisterskich w „małej, lokalnej uczelni”, na której zajęcia praktyczne cieszą się szacunkiem i są traktowane bardzo poważnie, jako niezbędny element przygotowania nauczycieli do wykonywania zawodu (środowisko). Twierdzi, że jej zadaniem jest dobre przygotowanie studentów do pracy (misja). Uważa się za nauczyciela, który powinien wytłumaczyć studentom to, czego nie rozumieją i odpowiednio ich ukierunkować, bowiem ma duże doświadczenie i rozumie, „co oznacza być nauczycielem języka w szkole” (tożsamość). Jest przekonana, że studentom pomaga, „jak opowie się im pewną historyjkę” (przekonanie) i dlatego przedstawia im przykłady zachowań nauczycieli, które zaobserwowała podczas hospitacji praktyk, zdarzenia „charakterystyczne lub zabawne” czy „sytuacje zaskakujące” (kompetencje i zachowania).

\section{Andrzej}

Andrzej jest nauczycielem prowadzącym zajęcia z dydaktyki języka obcego dla studentów filologii angielskiej oraz warsztaty dla nauczycieli już pracujących w różnych miejscach, bowiem są one przygotowywane za zamówienie (środowisko). Uważa, że w jego pracy najważniejsze jest, aby „doprowadzić studentów do jakiegoś kolejnego etapu” w edukacji (misja). Za swoje główne zadanie nauczyciela uważa takie prowadzenie zajęć, „aby osoba, która przychodzi po coś, wyszła z tym czymś i była zadowolona z tego, co otrzymała" (misja). Na zajęciach stara się „promować humanistyczne podejście do drugiego człowieka" (przekonanie), co robi poprzez podawanie celowo wybranych przykładów z życia, prowokuje uczniów, aby się z nim nie zgadzali i prezentowali swój pogląd i własną opinię, poszukuje informacji zwrotnych dotyczących swoich zajęć i odczuć studentów (kompetencje i zachowania). Cechą fundamentalną Andrzeja, jego zdaniem, jest szacunek do drugiego człowieka (tożsamość).

1 Wyniki całości badań i ich interpretacja znajdują się w mojej monografii z 2019 roku. 


\section{Irena}

Irena prowadzi zajęcia z glottodydaktyki i edukacji wielokulturowej na filologii angielskiej i niemieckiej (środowisko). Twierdzi, że jej rolą jest wspomaganie rozwoju drugiego człowieka (misja). Uważa się za nauczyciela demokratycznego (tożsamość) i wiele aspektów zajęć ustala ze studentami (kompetencje i zachowania). Myśli, że studenci doceniają jej autentyczność i duże doświadczenie zawodowe (przekonanie), dlatego podczas zajęć stara się „opierać na refleksji i doświadczeniu”, często nawiązuje do własnych przeżyć i podsuwa swoje pomysły na rozwiązywanie problemów (kompetencje i zachowania). Irena okazuje wiele ciepła innym i jest im przyjazna, buduje swoje relacje na wzajemnej pomocy i poszanowaniu własnego ja (cechy fundamentalne, zachowanie).

\section{Rafat}

Rafał prowadzi konwersatoria i ćwiczenia z glottodydaktyki na filologii angielskiej i zakłada, że jego studenci są zainteresowani jego zajęciami, bowiem "są tam, gdzie chcą być” (środowisko). Za sukces uważa "przekazanie swojej własnej pasji studentom” (misja). Nazywa siebie „refleksyjnym praktykiem", bowiem dużo myśli o tym, jak uczy i jak może jeszcze poprawić swój styl pracy (tożsamość). Jest przekonany, że wiele rzeczy w pracy nauczyciela jest związanych z rzemiosłem i jest „wyuczalnych” (przekonanie) i dlatego wprowadza podczas swoich zajęć „bardzo silny komponent warsztatowy” (kompetencje i zachowania).

\section{Zofia}

Zofia prowadziła przez kilka ostatnich lat zajęcia z metodyki nauczania języka angielskiego, głównie na specjalności edukacja wczesnoszkolna i przedszkolna, jest także autorką bloga poświęconego metodyce i pracy nauczyciela, który cieszy się wielką popularnością nie tylko wśród jej studentów (środowisko). Uważa, że jej głównym zadaniem, jako nauczyciela, jest dzielenie się wiedzą i doświadczeniem z innymi (misja). Stwierdza, że zawód nauczyciela akademickiego jest nobilitujący, a jej droga zawodowa to "praca od podstaw" (tożsamość). Jest przekonana, że „czasami chaos w klasie może być twórczy” (przekonania) i dlatego stosuje "bardziej aktywne formy pracy ze studentami” - metody aktywizujące i angażujące studentów, zadaje pytania problemowe i poszukuje nowych form pracy (zachowania i kompetencje). Jest bardzo ciekawa świata i szanuje taką cechę u innych (cechy fundamentalne).

Głównym wnioskiem $\mathrm{z}$ analizy powyższych wypowiedzi w oparciu o „model cebuli” jest fakt nierozerwalnego przenikania warstw i ich wzajemnych 
relacji. Nauczyciele oczywiście nie są świadomi wielu swoich „warstw” lub cech podstawowych, lecz każda świadoma decyzja jest potwierdzeniem ich istnienia. Widoczne działanie nauczycieli jest uwarunkowane harmonią panującą pomiędzy wszystkimi wymienionymi warstwami i płynie w rzeczywistości z „głębi”. Cechy indywidualne nauczycieli, ich osobowość, tożsamość, przekonania i kompetencje determinują zastosowane strategie nauczania, a w rezultacie stanowią o jakości nauczania i stwarzaniu możliwości uczenia się przez uczniów lub studentów. Fakt ten jest niezmiernie ważny w kontekście kształcenia kadr nauczycielskich. Widoczna jest konieczność przebudowania koncepcji kształcenia skupionych głównie na rozwoju kompetencji, ujęcia niemal rzemieślniczego. Działania takie są zbyt jednokierunkowe i, zgodnie z założeniami „modelu cebuli”, nie gwarantują możliwości sensownego i wartościowego ukształtowania prawdziwego, dobrego nauczyciela. Konieczne jest wieloaspektowe podejście do samego procesu uczenia się oraz planowanie kształcenia nauczycieli jako procesu wielopoziomowego, który odnosi się do poszczególnych warstw tytułowej „cebuli”.

\section{Zakończenie}

Dokonując analizy prac naukowych poświęconych profesjonalizmowi nauczyciela i jakości jego pracy, otrzymuje się obraz rozczłonkowany, nadmiernie „rozłożony na czynniki pierwsze”. Stąd moje zainteresowanie „modelem cebuli”, który stanowi swoiste połączenie wielotorowych badań nad profesjonalizmem nauczyciela i wyjaśnia, skąd wywodzi się prawdziwa i rzeczywista jakość nauczycielska. Korthagen spogląda bowiem z jednej strony szerzej na nauczyciela, ukazując jego środowisko i doświadczenia, z drugiej analitycznie wskazuje poszczególne „warstwy” warunkujące jego profesjonalizm. Zabieg taki przynosi zaskakujące efekty, bowiem poprzez rozczłonkowanie Korthagen buduje całość.

Opisywany model podkreśla konieczność całościowego zrozumienia profesjonalizmu nauczyciela i spojrzenia na jakość jego pracy z perspektywy przenikających się „warstw” i cech, często niewidocznych, oraz modernizacji procesu kształcenia nauczycieli opartego na samym tylko rozwijaniu ich kompetencji (a więc ujęcia rzemieślniczego). Poznać można bowiem tylko warstwę zewnętrzną tytułowej „cebuli”, zaś odkrycie prawdziwej natury nauczyciela jest możliwe tylko dzięki dotarciu do jej wnętrza i zrozumieniu jak owo wnętrze „przepływa” przez poszczególne warstwy, modyfikując je i rozbudowując. I choć nie widać warstw głębokich „cebuli”, to jednak ich ujawnienie się jest odczuwalne w zachowaniach nauczyciela. Poprzez działanie wskazuje on, czy jest dobrym nauczycielem, skutecznym pedagogiem 
i aktywnym wykładowcą, służbistą, czy nudziarzem. Z jego „wnętrza” pochodzi bowiem wartość sięgająca poza wyuczoną wiedzę czy nabyte kompetencje rzemieślnicze - prawdziwa jakość nauczania.

\section{BIBLIOGRAFIA}

Babicka-Wirkus, A. (2019). Kultury oporu w szkole. Działania - motywacje - przestrzeń. Warszawa: Wolters Kluwer.

Caprara, G.V., Cervone, D. (2003). A concept of personality for a psychology of human strengths: Personality as an agentic, self-regulating system. W: L.G. Aspinwall, U.M. Staudinger (red.), A psychology of human strengths (s. 61-74). Washington, DC: American Psychological Association. Pozyskano z: https://pl.scribd.com/doc/113772919/A-Psychology-of-Human-Strengths-Fundamental-Questions-and-Future-Directions-for-a-PositivePsychology-1, [data dostępu: 18.01.2017].

Czerepaniak-Walczak, M. (2015). Kultura szkoły - o jej złożoności i wielowymiarowości. Pedagogika Społeczna, 3(57), 77-87.

Ekizer, F.N., Cephe, P.T. (2017). Actualization of the onion model of reflection in Tirkish English Language instructors' practices: A case study. Educational Research and Reviews, 12(2), 62-72.

Fisher, M.H., (2011). Factors influencing stress, burnout, and retention of secondary teachers. Current Issues in Education, 14(1). Pozyskano z: http://cie.asu.edu/ojs/index.php/cieatasu/ article/viewArticle/658

Gołębniak, B.D. (200o). Postawy, przekonania i wiedza praktyczna nauczycieli. W: M. Cylkowska-Nowak (red.), Edukacja. Społeczne konstruowanie idei i rzeczywistości (s. 237-254). Poznań: Wolumin.

Hamachek, D. (1999). Effective teachers: What they do, how they do it, and the importance of self-knowledge. W: R.P. Lipka, T.M. Brinthaupt (red.), The role of self in teacher development (s. 189-224). Albany: State University of New York Press. Za: Korthagen, F., Vasalos, A. (2008). Quality from within as the key to professional development. Referat na spotkaniu American Educational Research Association, New York, March. Pozyskano z: http://post. queensu.ca/ ste/AERA2008/korthagen.pdf, [data dostępu: 10.01.2017].

Hattie, J. (2009). Visible learning. A Synthesis of over 800 Meta-Analyses Relating to Achievement. Abingdon: Routledge.

Holmes, M. (1998). Change and tradition in education: The loss of community. W: A. Hargreaves, A. Lieberman, M. Fullan, D. Hopkins (red.), International handbook of educational change (s. 558-575). Dordrecht-Boston-London: Kluwer. Za: Korthagen, F., Vasalos, A. (2008). Quality from within as the key to professional development. Referat na spotkaniu American Educational Research Association. New York, March. Pozyskano z: http://post. queensu.ca/ ste/AERA2008/korthagen.pdf, [data dostępu: 10.01.2017].

Illeris, K. (2006). Trzy wymiary uczenia się. Wrocław: Wydawnictwo Naukowe Dolnośląskiej Szkoły Wyższej Edukacji TWP.

Klus-Stańska, D. (2010). Dydaktyka wobec chaosu pojęć i zdarzeń. Warszawa: Wydawnictwo Akademickie Żak.

Kolb, D. (1984). Experiential Learning. Experience as the source of learning and development. Englewood Cliffs; London: Prentice-Hall.

Körkkö, M. (2019). Towards meaningful reflection and a holistic approach: Creating a reflection framework in teacher education. Scandinavian Journal of Educational Research. Advance online publication. DOI:10.1080/00313831.2019.1676306

Korthagen, F.A.J. (2004). In search of the essence of a good teacher: Towards a more holistic approach in teacher education. Teaching and Teacher Education, 20(1), 77-97.

Korthagen, F.A.J., Kessels, J., Koster, B., Lagerwerf, B., Wubbels, T. (2001). Linking practice and theory: The pedagogy of realistic teacher education. Mahwah, NJ: Lawrence Erlbaum 
Associates. Pozyskano z: http://resources.educ.queensu.ca/ar/aera2001/Korthagen20o1. pdf, [data dostępu: 10.01.2017].

Korthagen, F.A.J., Vasalos, A. (2008). Quality from within as the key to professional development. Referat na spotkaniu American Educational Research Association. New York, March. Pozyskano z: http://post.queensu.ca/ ste/AERA2008/korthagen.pdf, [data dostępu: 10.01.2017].

Mazurkiewicz, G. (2011). Ewaluacja w nadzorze pedagogicznym. Refleksje. Kraków: UJ.

McInyre, D., Hagger, H. (1992). Professional development through the Oxford Internship Model. British Journal of Educational Studies, 40(3), 264-283.

Mizerek, H. (1999). Dyskursy współczesnej edukacji nauczycieli. Między tradycjonalizmem a ponowoczesnością. Olsztyn: Wydawnictwo UWM.

Nowosad, I. (2019). Kultura szkoły w rozwoju szkoły. Kraków: Oficyna Wydawnicza Impuls.

Ofman, D.D. (2000). Core qualities: A gateway to human resources. Schiedam: Scriptum. Za: Korthagen, F., Vasalos, A. (2008). Quality from within as the key to professional development. Referat na spotkaniu American Educational Research Association, New York, March. Pozyskano z: http://post.queensu.ca/ ste/AERA2008/korthagen.pdf, [data dostępu: 10.01.2017]

Sööt, A., Viskus E. (2015). Reflection on Teaching: A Way to Learn from Practice. Procedia, Social and Behavioral Sciences, 191, 1941-1946.

Szplit, A. (2019). Od nowicjusza do eksperta. Rozwój ekspertywności nauczycieli nauczycieli języków obcych. Kielce: UJK.

Ward, R.E., Burke, M.A. (2004). Improving Achievement Low Performing School. Key Results for School Leaders. London: Sage.

Zwart, R.C., Korthagen, F.A.J., Attema-Noordewier, S. (2014). A strength-based approach to teacher professional development, Professional Development in Education. DOI: 10.1080/1 9415257.2014 .919341

\section{SUMMARY}

\section{Teacher quality from the core - discussion on Fred Korthagen „onion model”}

The text presents an important contemporary concept - Fred Korthagen's „onion model”. It indicates its grounding in scientific studies and its adequacy to the discussion on educational changes and teacher professionalism. The author also uses it to build the profiles of academic teachers among whom she conducted the interviews. As a result of these endeavors, she shows the harmony between the layers of the "onion” and the „flow” of the teacher's quality from within.

KEY WORDS: teacher, onion model, quality of teaching, competences 